\title{
Characterization of endoglin on mouse uterine stromal cells
}

\author{
M-J. Ouellette ${ }^{1,2}$, L. Hamel ${ }^{3}$, N. Tremblay ${ }^{3}$, M. Lamothe ${ }^{1}$ and S. St-Jacques ${ }^{2,4 *}$ \\ 'Unité de Recherche en Ontogénie et Reproduction, Centre de Recherche du Centre Hospitalier, Universitaire de Québec, Pavillon CHUL, \\ Ste-Foy, Québec, Canada G1V 4G2; ${ }^{2}$ Centre de Recherche en Biologie de la Reproduction, Université Laval, Ste-Foy, Quebec, Canada; \\ ${ }^{3}$ Centre de Recherche Guy-Bernier, Hôpital Maisonneuve-Rosemont, Montréal, Québec, Canada H1T 2M4; and ${ }^{4}$ Département \\ d'Obstétrique et Gynécologie, Université Laval, Ste-Foy, Québec, Canada
}

\begin{abstract}
During the oestrous cycle and early pregnancy, the uterus undergoes a variety of morphological and physiological modifications involving uterine cell proliferation and differentiation as well as extensive tissue remodelling. Transforming growth factor $\beta$ (TGF- $\beta$ ) has powerful effects on these events and thus is thought to have a critical role in uterine physiology. Endoglin is a transmembrane glycoprotein that binds TGF- $\beta 1$ and $-\beta 3$ and interacts with TGF- $\beta$ signalling receptors to modulate many effects of this growth factor in different types of cell. Studies in mice revealed the highest concentrations of endoglin in the reproductive tract, notably on stromal cells of cyclic and pregnant uteri. The objective of the present study was to investigate the role of endoglin expressed on uterine stromal cells in binding TGF- $\beta$ and in the cellular responses induced by this growth factor. Highly purified populations of uterine stromal cells were isolated by cell affinity to the monoclonal antibody MJ7/18, which is specific to mouse endoglin. Affinity labelling of these cells with ${ }^{125}$ I-labelled TGF- $\beta$ followed by immunoprecipitation with endoglin-specific polyclonal $1256: 4 \mathrm{~b}$ antiserum indicated that endoglin expressed at the surface of uterine stromal cells binds TGF- $\beta 1$ and interacts with TGF- $\beta$ signalling receptors. Treatment of uterine stromal cells with different concentrations of TGF- $\beta 1$ induced a biphasic proliferative response and addition of MJ7/18 as well as neutralizing TGF- $\beta$ antibodies showed endoglin to be a modulator of TGF- $\beta$-induced stromal cell proliferation. Given the importance of TGF- $\beta$ in the regulation of uterine physiology, these results indicate a role for endoglin during uterine tissue remodelling and decidualization.
\end{abstract}

\section{Introduction}

The endometrium is a dynamic tissue that responds to steroids, cytokines and growth factors to accommodate, regulate and sustain developing embryos. Among these cytokines and growth factors, transforming growth factor $\beta$ (TGF- $\beta$ ) appears to be critical to endometrial functions (for review see Godkin and Doré, 1998). TGF- $\beta$ and its receptors are present in both cyclic and pregnant uteri in different species (Tamada et al., 1990; Manova et al., 1992; Chegini et al., 1994; Roelen et al., 1994; Tang et al., 1994; Das et al., 1997; Ando et al., 1998). Cyclic growth and tissue remodelling of the uterus occur throughout reproductive life during the oestrous cycle and trophoblastic invasion (Iwahashi et al., 1996). TGF- $\beta$ stimulates DNA synthesis in endometrial stromal cells, whereas it inhibits uterine epithelial cell proliferation (Rotello et al., 1991; Hammond et al., 1993; Marshburn et al., 1994; Tang et al., 1994; Dumont et al., 1995). Tissue remodelling involves controlled enzymic degradation of extracellular matrix (ECM) (Bischof et al., 1993; Rodgers et al., 1994) as well as dynamic

*Correspondence address: Ontogénie et Reproduction, Centre de Recherche du Centre Hospitalier, Universitaire de Québec, Pavilton CHUL, 2705 boul. Laurier, Ste-Foy, Québec, Canada G1V 4G2.

Received 20 November 1998. temporal and spatial patterns of integrin expression, mirroring the changes in ECM proteins (Tabibzadeh, 1992; Lessey et al., 1994). TGF- $\beta$ stimulates the synthesis of laminin and collagen IV by endometrial stromal cells (Ueda et al., 1992) and induces the expression of the $\alpha 1 \beta 1$ collagen-laminin receptor at the surface of these cells (Grosskinsky et al., 1996). TGF- $\beta$ produced in the uterine stroma under the influence of progesterone mediates the suppression of epithelial metalloproteinases (Bruner et al., 1995). Similarly, TGF- $\beta 1$ significantly influences the plasminogen-activating system in endometrial stromal cells (Ueda et al., 1992; Sandberg et al., 1997; Casslén et al., 1998). During implantation, endometrial TGF- $\beta 1$ regulates the invasion of trophoblastic cells by modulation of their proteolytic activity and by promoting differentiation of invasive trophoblast into non-invasive multinucleated giant cells (Graham and Lala, 1992). Furthermore, TGF- $\beta$ is a key molecule for the local suppression of immune effector cells in the uterus and thus for protection of the fetoplacental unit from rejection (Clark et al., 1990).

TGF- $\beta$ exerts its biological effects by binding to highly specific cell surface receptors including type I and type II receptors (T $\beta R I$ and T $\beta R I I)$, as well as the type III receptor betaglycan (for review see Miyazono, 1997). T $\beta R I$ and TRRII are related transmembrane serine-threonine kinases that 
associate in the presence of ligand to mediate TGF- $\beta$ signals (Wrana et al., 1992). Betaglycan, a membrane-anchored proteoglycan without an intracellular kinase domain, presents the ligand to TRRII, thus enhancing cell responsiveness (Lopez-Casillas et al., 1991, 1993). TGF- $\beta$ first binds to T $\beta R I I$, which is constitutively autophosphorylated. $T \beta R I$ is then recruited into the complex and phosphorylated by T $\beta$ RII to initiate downstream signalling cascades (Ventura et al., 1994; Wrana et al., 1994; Chen et al., 1995). Activated TßRI phosphorylates Smads (Drosophilia, mothers against dpp homologues) proteins, a family of downstream targets, which translocate to the nucleus in which they may induce gene transcription (Massagué, 1996; Heldin et al., 1997).

Endoglin, also known as CD105 (Letarte et al., 1994), is a homodimeric transmembrane glycoprotein that is structurally related to betaglycan and binds TGF- $\beta 1$ and $-\beta 3$ with high affinity (Gougos and Letarte, 1990; Lopez-Casillas et al., 1991; Cheifetz et al., 1992). In the presence of ligand, endoglin forms heteromeric complexes with T $\beta R I$ and T $\beta R I I$ and, despite the absence of signalling motif, modulates cellular responses to TGF- $\beta$ in different types of cell (Yamashita et al., 1994; Lastres et al., 1996; Caniggia et al., 1997). Transfection of endoglin cDNA into the U-937 monocytic line totally abrogated the inhibition of cellular proliferation and the associated increase in c-myc transcript induced by TGF- $\beta 1$ (Lastres et al., 1996). Exposure of human villous explants from first trimester pregnancy to endoglin monoclonal antibody 44G4, neutralizing TGF- $\beta$ antibodies, or endoglin antisense oligonucleotides, stimulated trophoblast cell outgrowth and migration (Caniggia et al., 1997). The discovery that endoglin is the gene for hereditary haemorrhagic telangiectasia type 1 , an autosomal dominant disorder characterized by multisystemic vascular displasia and recurrent haemorrhage (McAllister et al., 1994), confirms the importance of this molecule in the mediation of TGF- $\beta$ effects in vivo. These findings identify endoglin as an important accessory protein of the TGF- $\beta$ receptor complex.

Although endoglin is characteristically expressed on vascular endothelial cells (Gougos and Letarte, 1988; O'Connell et al., 1992; Letarte et al., 1994), estimation of its relative concentration in mouse tissues by semi-quantitative RT-PCR revealed highest expression in tissues of the reproductive tract, notably in the uterus in which endoglin co-localizes with TGF- $\beta$ secreted in the stroma (St-Jacques et al., 1994). Given the importance of TGF- $\beta$ in uterine physiology (Flanders et al., 1991; Godkin and Doré, 1998) and the regulatory functions attributed to endoglin in the mediation of cell responses induced by TGF- $\beta$ (Lastres et al., 1996; Caniggia et al., 1997), the purpose of this study was to determine whether endoglin expressed by mouse uterine stromal cells interacts with TGF- $\beta$ receptors and participates in cell proliferation induced by TGF- $\beta$.

\section{Materials and Methods}

\section{Animals}

Randomly bred female CD1 mice at 5-10 weeks of age (Charles River Laboratories, St Constant, Québec) were used to provide uterine cells. Experiments were carried out in accordance with the procedures described in the guidelines for the care and use of laboratory animals as approved by the institution's animal care committee.

\section{Isolation and culture of uterine cells}

Cells were isolated from mouse uterine horns by a combination of enzymic and mechanical dispersion techniques adapted from protocols described in the literature (Chegini et al., 1992; Hammond et al., 1993; Zhang et al., 1995). Mice were killed by $\mathrm{CO}_{2}$ inhalation, and uterine horns were excised and opened into Dulbecco's modified Eagle medium: nutrient mixture F12 (D-MEM/F-12) (Gibco BRL, Burlington, Ontario). Epithelial cells were recovered by enzymic digestion $\left(60 \mathrm{~min}\right.$ at $37^{\circ} \mathrm{C}$ ) with $1 \mathrm{mg}$ collagenase type $\mathrm{I} \mathrm{ml}^{-1}$ (Sigma, St Louis, MO) in D-MEM/F12. A second enzymic digestion was performed by adding fresh collagenase solution to the tissues and shaking (140 rpm) for $30 \mathrm{~min}$ at $37^{\circ} \mathrm{C}$. The resulting suspension consisted of epithelial and stromal cells. Stromal cells were recovered by crushing the remaining tissues on a metal sieve $(200 \mu \mathrm{m})$. Cells were resuspended in D-MEM/F12 supplemented with $10 \%$ fetal bovine serum (FBS) (PDI Bioscience, Aurora, Ontario) and $1 \%(\mathrm{v} / \mathrm{v})$ penicillin (5000 U)-streptomycin (5 $\mathrm{mg} \mathrm{ml}^{-1}$ ) solution (Sigma), and cultured at $37^{\circ} \mathrm{C}$ in a humidified atmosphere of $5 \% \mathrm{CO}_{2}$.

\section{Characterization of uterine cells}

Epithelial and stromal cells were seeded at 1.5 and $2.0 \times$ $10^{4}$ cells per well, respectively, in tissue culture chamber slides (Nunc, Napierville, Québec) and allowed to attach for $48 \mathrm{~h}$. Slides were washed with Dulbecco's PBS (DPBS) and cell membranes were permeabilized by a 5 min incubation in a solution of acetone:methanol (1:1). After washes with DPBS, slides were incubated for $2 \mathrm{~h}$ at $37^{\circ} \mathrm{C}$ with polyclonal rabbit anti-mouse vimentin or rabbit anti-human panCytokeratin (ICN, Montréal, Québec) diluted 1:25 in PBS. Normal rabbit serum was used as a control. The cells were washed in PBS and incubated for $60 \mathrm{~min}$ at $37^{\circ} \mathrm{C}$ with fluorescein isothiocyanate (FITC)-conjugated goat antirabbit IgG (Sigma) diluted 1:25 in PBS. Slides were washed with PBS and immunostaining was observed using a fluorescence microscope.

\section{Preparation of endoglin-positive uterine stromal cell populations}

Stromal cells isolated by enzymic digestion were cultured for 3 days in D-MEM/F12 supplemented with 10\% FBS. Near-confluent monolayers were detached with trypsinEDTA (Gibco BRL), washed twice and resuspended in PBS $\left(5 \times 10^{6}\right.$ cells $\left.\mathrm{ml}^{-1}\right)$. Cells were then incubated for $30 \mathrm{~min}$ at $4^{\circ} \mathrm{C}$ with MJ7/18 hybridoma supernatant containing mouse endoglin monoclonal antibody $(\mathrm{mAb})$ (Standford University School of Medicine, Standford, CA; Ge and Butcher, 1994). 
The cells were washed in PBS and incubated for $20 \mathrm{~min}$ at $4^{\circ} \mathrm{C}$ with FITC-conjugated goat anti-rat $\operatorname{IgG}\left(8 \mu \mathrm{g} \mathrm{ml}^{-1}\right)$ (Sigma). After incubation, the cells were washed, resuspended in PBS $\left(5 \times 10^{6}\right.$ cells $\left.\mathrm{ml}^{-1}\right)$, and sorted by flow cytometry. Endoglin-positive stromal cells were recovered and maintained in D-MEM/F12 supplemented with $10 \%$ FBS. These cells were used for affinity labelling and proliferation assays after a first passage.

\section{TGF- $\beta$ affinity labelling and immunoprecipitation}

Affinity labelling was performed as described by Mitchell et al. (1992). Briefly, endoglin-positive cells were seeded at $2 \times$ $10^{5}$ cells per well in a 12-well plate. Near-confluent cell monolayers were washed for $30 \mathrm{~min}$ with ice-cold binding buffer (DPBS with $\mathrm{Mg}^{2+}$ and $\mathrm{Ca}^{2+}, \mathrm{pH} 7.4$, containing $0.1 \%$ $\mathrm{BSA}$; Sigma) and incubated on ice for $4 \mathrm{~h}$ with $100 \mathrm{pmol}{ }^{125} \mathrm{I}-$ labelled TGF- $\beta 11^{-1}$ (Mandel, Guelph, Ontario) with or without $4 \mathrm{nmol}$ competing unlabelled TGF- $\beta 1 \mathrm{l}^{-1}$. The receptor-ligand complexes were crosslinked with $2 \mathrm{mmol}$ bis(sulfosuccimidyl)suberate $\mathrm{l}^{-1}$ (Pierce, Rockford, IL). Cells were washed with DPBS and solubilized in a buffer containing $1 \%(\mathrm{v} / \mathrm{v})$ Triton-X100, 10\% glycerol, 1 mmol EDTA $\mathrm{l}^{-1}, 20 \mathrm{mmol}$ Tris- $\mathrm{HCl} \mathrm{l}^{-1}, \mathrm{pH} 7.4$, and a mixture of proteolytic inhibitors containing $1 \mathrm{mmol}$ phenylmethylsulfonylfluoride $\mathrm{l}^{-1}, 20 \mu \mathrm{g}$ aprotinin $\mathrm{ml}^{-1}, 20 \mu \mathrm{g}$ soybean trypsin inhibitor $\mathrm{ml}^{-1}$ and $25 \mathrm{mmol}$ benzamidine $\mathrm{l}^{-1}$ (Boehringer Mannheim, Laval, Québec). Cell lysates were either analysed directly by SDSPAGE or were immunoprecipitated overnight with $40 \mu \mathrm{g}$ rabbit polyclonal antibody $1256: 4 \mathrm{~b}$ raised against human endoglin (Hospital for Sick Children, Toronto, Ontario) (Gougos and Letarte, 1990) or preimmune serum. Immune complexes were precipitated for $2 \mathrm{~h}$ at $4^{\circ} \mathrm{C}$ with protein GSepharose (Pharmacia, Baie d'Urfé, Québec) slurry consisting of $50 \%$ packed beads in DPBS and $1 \%(\mathrm{v} / \mathrm{v})$ Triton$\mathrm{X} 100$. Extracts and radiolabelled endoglin complexes were fractionated on $4-12 \%$ SDS-PAGE under non-reducing and reducing conditions and visualized by autoradiography.

\section{[3H]thymidine incorporation assay}

Proliferation of endoglin-positive uterine stromal cells in response to TGF- $\beta$ was studied by evaluating $\left[{ }^{3} \mathrm{H}\right]$ thymidine incorporation into trichloroacetic acid-precipitable material using a method adapted from protocols for human endometrial stromal cells (Tang et al., 1994; Dumont et al., 1995). Cells were seeded at $2.5 \times 10^{4}$ cells per well in 96-well microtitre culture plates (Falcon, Toronto, Ontario) in D$\mathrm{MEM} / \mathrm{F} 12$ supplemented with $10 \% \mathrm{FBS}$. At $24 \mathrm{~h}$ after plating, cells were washed with $\mathrm{Mg}^{2+}$ - and $\mathrm{Ca}^{2+}$-free PBS and incubated in 2\% FBS-supplemented D-MEM/F12 medium in the presence of different concentrations of TGF- $\beta 1(0-10 \mathrm{ng}$ $\mathrm{ml}^{-1}$ ) with or without $15 \mu \mathrm{g}$ per well of $\mathrm{mAb}$ MJ7/18, Pan specific TGF- $\beta$ neutralizing antibody (R\&D Systems, Minneapolis, MN), or non-immune rat IgG (Sigma). After 48 h, $0.2 \mu \mathrm{Ci}\left[{ }^{3} \mathrm{H}\right]$ thymidine (NEN, Mississauga, Ontario) was added to each well and the incubation was continued for a further 18-24 h. Cells were then detached with
trypsin-EDTA, harvested onto filter paper discs with a multiple cell harvester (Fisher Scientific Ltd, Neapan, Ontario), and the incorporated radioactivity was measured by liquid scintillation counting. Two assays were performed in triplicate using three different cell preparations.

\section{Statistical analysis}

Increases in stromal cell proliferation induced by TGF- $\beta 1$ were analysed individually using $t$ tests. A modified $t$ test (in which variances are pooled) was used to compare unilaterally, at each concentration of TGF- $\beta 1$ tested, differences in the increase in cell proliferation between groups with and without antibodies. The same test was also performed to confirm the stimulatory effect of MJ7/18 antibody at a TGF- $\beta 1$ concentration of $2 \mathrm{ng} \mathrm{ml}^{-1}$.

\section{Results}

Isolation of uterine cells expressing endoglin

A protocol derived from established procedures (Chegini et al., 1992; Hammond et al., 1993; Zhang et al., 1995) was used to prepare primary cultures of uterine cells from mature randomly cyclic mice. Uterine epithelial cells were recovered after a first digestion step with collagenase. Cells attached over a period of $72 \mathrm{~h}$ after plating and showed a typical cuboidal morphology (Fig. 1a). They were specifically stained with antibody directed against cytokeratin (Fig. 1c), which is a marker for epithelial cells (Chegini et al., 1992; Zhang et al., 1995). Stromal cells were released after additional enzymic digestion followed by grinding of the remaining uterine tissue. Live cells attached to the culture dishes within $18 \mathrm{~h}$, whereas other contaminating cells, such as dead cells and epithelial cells, were eliminated by replacement of the culture medium. These cells showed a typical fibroblast-like morphology (Fig. 1b) and expressed high concentrations of vimentin (Fig. 1d), a marker for fibroblastic cells (Chegini et al., 1992; Mani et al., 1992; Mulholland et al., 1992). They did not express cytokeratin. At the time of plating, both types of cell showed a cell viability $>95 \%$.

Flow cytometric analysis of viable stromal cell populations (Fig. 2a) revealed that approximately $60 \%$ of these cells express endoglin at their surface, as determined by labelling with $\mathrm{mAb} \mathrm{MJ} / 18$, which is specific to mouse endoglin (Fig. 2b). Highly purified populations of endoglinpositive uterine stromal cells were then isolated by cell sorting (Fig. 2c) to perform functional studies. Antibodies bound to the cell surface were released after a few hours in culture and endoglin expression was stable for up to 10 days, as determined by flow cytometry using mAb MJ7/18 (data not shown). The doubling time of these cells was $48 \mathrm{~h}$ when seeded at $1 \times 10^{4}$ cells $\mathrm{cm}^{-2}$. The populations of endoglinpositive cells showed a typical fibroblast-like morphology, expressed high concentrations of vimentin, and did not contain any macrophages or endothelial cells, which are both endoglin-expressing cells, as confirmed by immunostaining 
(a)
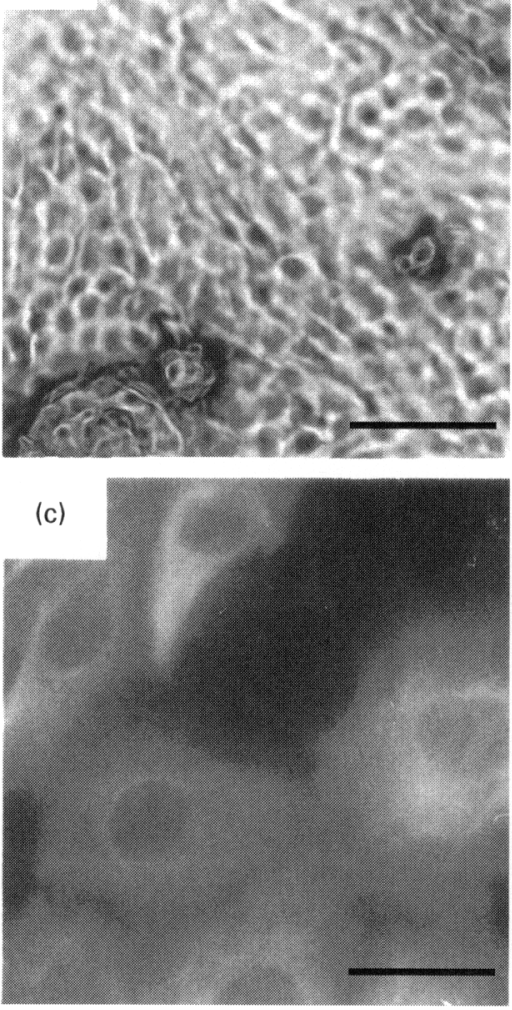

(b)

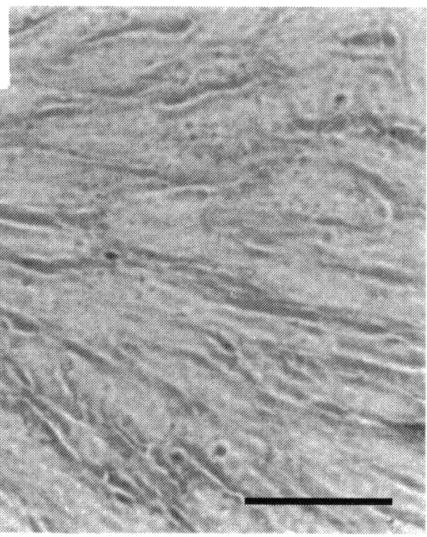

(d)

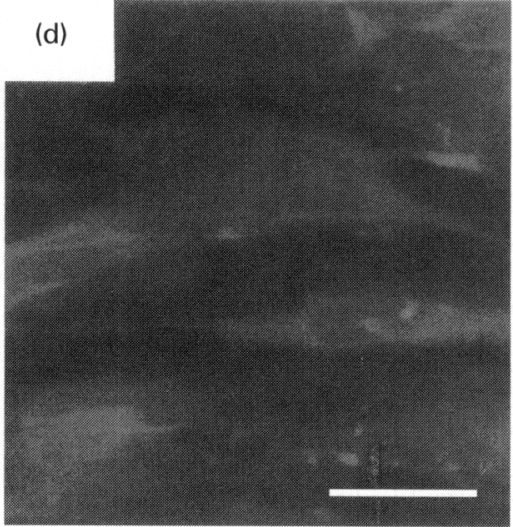

Fig. 1. Isolation and culture of mouse uterine cells. Epithelial cells were recovered after enzymic digestion of mouse uterine horns with collagenase type I. Stromal cells were isolated after an additional enzymic digestion followed by grinding and sieving of the remaining uterine tissues. After a few days in culture, epithelial cells showed a typical cuboidal morphology (a), while stromal cells showed a fibroblast-like morphology (b). Characterization of both types of cell by immunocy tochemistry with antibodies specific to cytokeratin and vimentin revealed the expression of cytokeratin by epithelial cells (c) and vimentin by stromal cells (d). Scale bars represent $200 \mu \mathrm{m}$ (a, b) and $50 \mu \mathrm{m}(\mathrm{c}, \mathrm{d})$.

with antibodies specific for $\mathrm{F} 4 / 80$ antigen and von Willebrand factor, respectively (data not shown).

\section{Expression of endoglin at the surface of uterine stromal cells and binding of TGF- $\beta 1$}

Endoglin-positive uterine stromal cells were affinity labelled with ${ }^{125} \mathrm{I}$-labelled TGF- $\beta 1$ and TGF- $\beta$-receptor complexes were analysed electrophoretically after chemical crosslinking and cell membrane solubilization. Autoradiograms of labelled complexes analysed by SDS-PAGE under reducing conditions (Fig. $3 \mathrm{a}$, lane $\mathrm{T}$ ) revealed four major bands of apparent relative molecular masses of 49, 67, 80-90 and $>150 \mathrm{kDa}$. Competition experiments using unlabelled TGF- $\beta 1$ confirmed the specificity of the labelling of the 67 , $80-90$ and $>150 \mathrm{kDa}$ complexes (Fig. 3b, lane T). The apparent molecular mass, binding specificity, and migration pattern of these binding complexes are characteristic of T $\beta R I, T \beta R I I$ and betaglycan (Massagué and Like, 1985; Cheifetz et al., 1986; Cheifetz et al., 1988). The similar intensity of the $49 \mathrm{kDa}$ band in the presence of an excess of unlabelled ligand indicated that this radiolabelled complex was not specific. Immunoprecipitation of affinity labelled complexes with the polyclonal antihuman endoglin serum 1256:4b, previously shown to react with mouse endoglin (St-Jacques et al., 1994), was performed after affinity crosslinking to determine whether TGF- $\beta$ complexes contained endoglin. The antiserum precipitated a major radiolabelled band of $167 \mathrm{kDa}$ in non-reducing conditions (Fig. 3a, line NR), which migrated as an affinity labelled band of $96 \mathrm{kDa}$ after reduction (Fig. 3a, line R). Faint bands, likely to correspond to T $\beta R I I$ and T $\beta R I$, co-immunoprecipitated with endoglin in the presence of ligand (Fig. 3a, lines NR and R). These complexes are not detected in the presence of an excess of unlabelled ligand (see Fig. 3b, lines R and NR). Free ${ }^{125} \mathrm{I}$-labelled TGF- $\beta 1$ migrated at $26 \mathrm{kDa}$ and non-specific labelling was observed at the top of the gels.

\section{Role of endoglin in the proliferation of uterine stromal cells} in response to TGF- $\beta 1$

Uterine stromal cell proliferation was measured using a $\left[{ }^{3} \mathrm{H}\right]$ thymidine incorporation assay. Results were expressed 

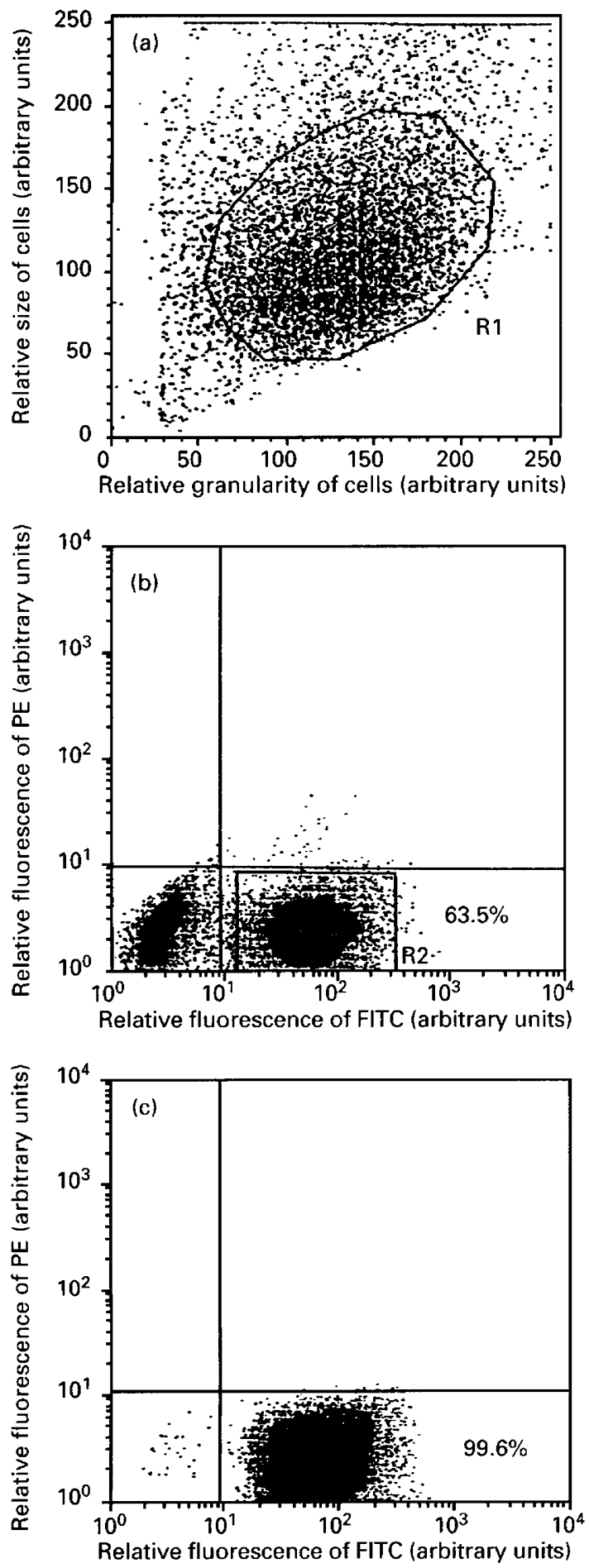

Fig. 2. Flow cytometric analysis of mouse uterine stromal cell population with monoclonal antibody $(\mathrm{mAb}) \mathrm{MJ} 7 / 18$. A viable stromal cell population isolated by collagenase digestion (a) was immunolabelled with mAb MJ7/18 specific to mouse endoglin. R1 represents the selected cell population. Approximately $60 \%$ of these cells expressed endoglin on the surface (b) as determined by incubation with rat anti-mouse endoglin followed by fluorescein isothiocyanate (FITC)-conjugated goat anti-rat IgG. Sorting of these cells allowed the isolation of a highly purified population (>99\%) of endoglin-positive uterine stromal cells (c). Cells that did not express endoglin are in the lower left-hand box $(b, c)$. PE: phycoerythrin. as a percentage increase compared with cell proliferation in the absence of TGF- $\beta 1$ and statistical analyses were performed on these values to take into consideration variations in basal cell proliferation rate among the different cell populations studied. The results are summarized (Fig. 4). A biphasic curve of cell proliferation was observed in response to TGF- $\beta 1$ (Fig. 4a). [ $\left.{ }^{3} \mathrm{H}\right]$ thymidine incorporation into DNA was significantly increased by approximately $20 \%$ after treatment with $0.02 \mathrm{ng}$ TGF- $\beta 1 \mathrm{ml}^{-1} \quad(P<0.025)$. Although TGF- $\beta 1$ significantly stimulated cell proliferation at $0.2 \mathrm{ng} \mathrm{ml}^{-1}(P<0.05)$, great variability was observed between responses in the three different cell preparations. At a concentration of $2 \mathrm{ng} \mathrm{ml}^{-1}$, TGF- $\beta 1$ had no significant effect on cell proliferation. Thymidine incorporation was stimulated by approximately $20 \%$ at a concentration of $5 \mathrm{ng} \mathrm{ml}^{-1} \quad(P<0.025)$ and by approximately $60 \%$ at $10 \mathrm{ng} \mathrm{ml}^{-1}(P<0.005)$.

$\mathrm{mAb} \mathrm{MJ7/18}$ was added to endoglin-positive cells in the presence of the ligand to determine whether endoglin had a role in the proliferation of uterine stromal cells in response to TGF- $\beta 1$ (Fig. $4 \mathrm{~b}$ ). In the presence of $\mathrm{mAb} \mathrm{MJ} 7 / 18$, the increase in DNA synthesis induced by TGF- $\beta 1$ at concentrations of $0.02(P<0.005)$ and $10.0 \mathrm{ng} \mathrm{m}^{-1}(P<0.025)$ was significantly inhibited. Conversely, at $2 \mathrm{ng} \mathrm{ml}^{-1}$, TGF- $\beta 1$ had no effect, whereas the addition of anti-endoglin significantly increased the rate of thymidine incorporation $(P<0.025)$. The specificity of the action of TGF- $\beta$ on $\left[{ }^{3} \mathrm{H}\right]$ thymidine incorporation was confirmed by using TGF- $\beta$ neutralizing antibodies $(P<0.01$ and 0.05$)$. Since the expression of both T $\beta$ RII and endoglin shows cyclic variation in the uterus (Takahashi et al., 1994; M-J. Bergeron, C. Brown, M-J. Ouellette and S. St-Jacques, unpublished), high standard deviations result from the comparison of cell populations isolated from randomly cyclic mice.

\section{Effect of TGF- $\beta 1$ on the expression of endoglin at the surface of uterine stromal cells}

Since the expression of endoglin is stimulated by TGF- $\beta 1$ on activated monocytes (Lastres et al., 1996) and bone marrow stromal cells (Robledo et al., 1998), its expression at the surface of uterine stromal cells treated with different concentrations of TGF- $\beta 1$ was verified by flow cytometric analysis. Cells were incubated with TGF- $\beta 1$ for $48 \mathrm{~h}$ and the expression of endoglin was studied using $\mathrm{mAb} \mathrm{MJ} 7 / 18$ and FITC-conjugated anti-rat IgG, as described for the preparation of endoglin-positive uterine stromal cells. Flow cytometric analysis showed that incubation with $0-5 \mathrm{ng}$ TGF- $\beta 1 \mathrm{ml}^{-1}$, concentrations known to stimulate the expression of endoglin in other types of cell (Lastres et al., 1996; Robledo et al., 1998), for $48 \mathrm{~h}$ did not affect either the percentage of endoglin-positive cells or the expression of endoglin (Fig. 5).

\section{Discussion}

Unlike most normal adult tissues, cyclic growth and remodelling occur within the uterus. Luminal and glandular epithelial cells, stromal cells and endothelial cells undergo 


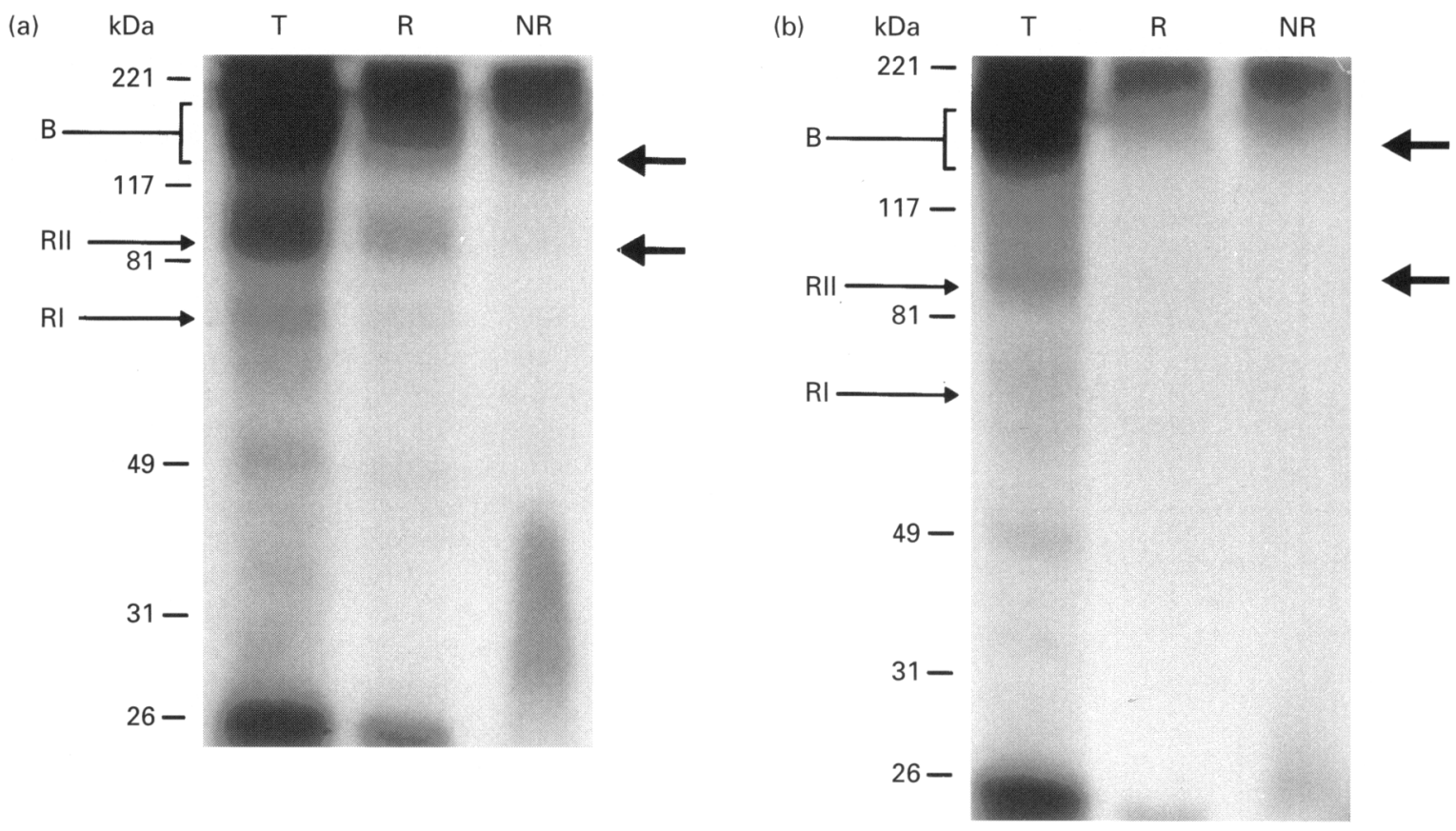

Fig. 3. Analysis of ${ }^{125}$ I-labelled transforming growth factor $\beta$ (TGF- $\beta$ ) affinity labelled membrane proteins of mouse uterine stromal cells. Endoglin-positive uterine stromal cells were affinity labelled with ${ }^{125}$ I-labelled TGF- $\beta 1$ and TGF- $\beta$-receptor complexes were analysed electrophoretically after chemical crosslinking. Endoglin- ${ }^{125}$ I-labelled TGF- $\beta 1$ complexes were identified after immunoprecipitation with polyclonal anti-human endoglin serum. Autoradiograms of Triton-X100 extracts of affinity labelled cells analysed by SDS-PAGE under reducing conditions ( $a$, lane T) revealed four major bands of apparent relative molecular masses of $49,67,80-90$ and $>150 \mathrm{kDa}$. In the presence of unlabelled TGF- $\beta 1$, radiolabelled complexes of $67,80-90$ and $>150 \mathrm{kDa}$ have been competed for by the specific ligand (b, lane $\mathrm{T}$ ), and are likely to correspond to type I transforming growth factor $\beta$ receptor (T $\beta R I$ ), T $\beta$ RII and betaglycan (B). The $49 \mathrm{kDa}$ radiolabelled band that has not been competed for is not specific for the ligand. Non-specific labelling was observed at the top of the gels. Polyclonal endoglin antiserum precipitated a major radiolabelled band of $167 \mathrm{kDa}$ under non-reducing conditions (a, lane NR) and of $96 \mathrm{kDa}$ after reduction $(a$, lane R). Faint bands, probably corresponding to T $\beta$ RII and T $\beta R I$, co-immunoprecipitated with endoglin in the presence of ligand ( $a$, lanes NR and R). These complexes are not detected in the presence of excess unlabelled ligand (b, lanes R and NR) confirming their specificity for TGF- $\beta 1$. Free ${ }^{125} \mathrm{I}$-labelled TGF- $\beta 1$ migrated at $26 \mathrm{kDa}$.

periods of proliferation, migration, differentiation and apoptosis. TGF- $\beta$ has potent effects on these processes and is thus thought to play a pivotal role in uterine physiology (Flanders et al., 1991; Shull and Doetschman, 1994; Godkin and Doré, 1998). Endoglin, a TGF- $\beta$-binding membrane glycoprotein, is highly expressed in mouse uterine stroma (Gougos and Letarte, 1990; Cheifetz et al., 1992; St-Jacques et al., 1994). The present study demonstrated that endoglin is expressed at the surface of uterine stromal cells, binds TGF$\beta 1$, interacts with signalling TGF- $\beta$ receptors and participates in the proliferation of stromal cells induced by this growth factor.

The specific localization of endoglin enabled the development of a highly reproducible and straightforward technique for the isolation and culture of endoglin-positive uterine stromal cells suitable for functional studies. In the mouse uterus, endoglin is expressed in the stroma, whereas epithelial and muscular cells are totally negative (St-Jacques et al., 1994). Freshly isolated uterine epithelial and stromal cells showed characteristic morphology and immunocytochemical staining for intermediate filaments (Chegini et al., 1992; Zhang et al., 1995). However, after 3 days in culture, immunocytochemical analysis of stromal cell populations revealed that only $60 \%$ of cells expressed endoglin at the surface. Contaminating epithelial cells, usually estimated as approximately 5\% (Bigsby et al., 1986; Jacobs and Carson, 1991; Chegini et al., 1992), are unlikely to account for this relatively high proportion of endoglinnegative cells. Indeed, immunohistochemical studies revealed that the expression of endoglin varies during the oestrous cycle (M-J. Bergeron, C. Brown, M-J. Ouellette and S. St-Jacques, unpublished). Since randomly cyclic mice were used for the isolation of uterine cells, it is likely that endoglin-low or endoglin-negative stromal cells isolated from mice in dioestrus, proestrus or metoestrus account for the lower than expected proportion of endoglin-positive cells observed after a few days in culture. It is critical that homogeneous populations of endoglin-positive uterine stromal cells are used in functional studies. Therefore, highly purified populations of stromal cells expressing endoglin were prepared by affinity to the monoclonal antibody MJ7/18, which is specific for mouse endoglin (Ge and Butcher, 1994).

Affinity labelling of endoglin-expressing stromal cells Downloaded from Bioscientifica.com at 04/26/2023 12:56:55PM 


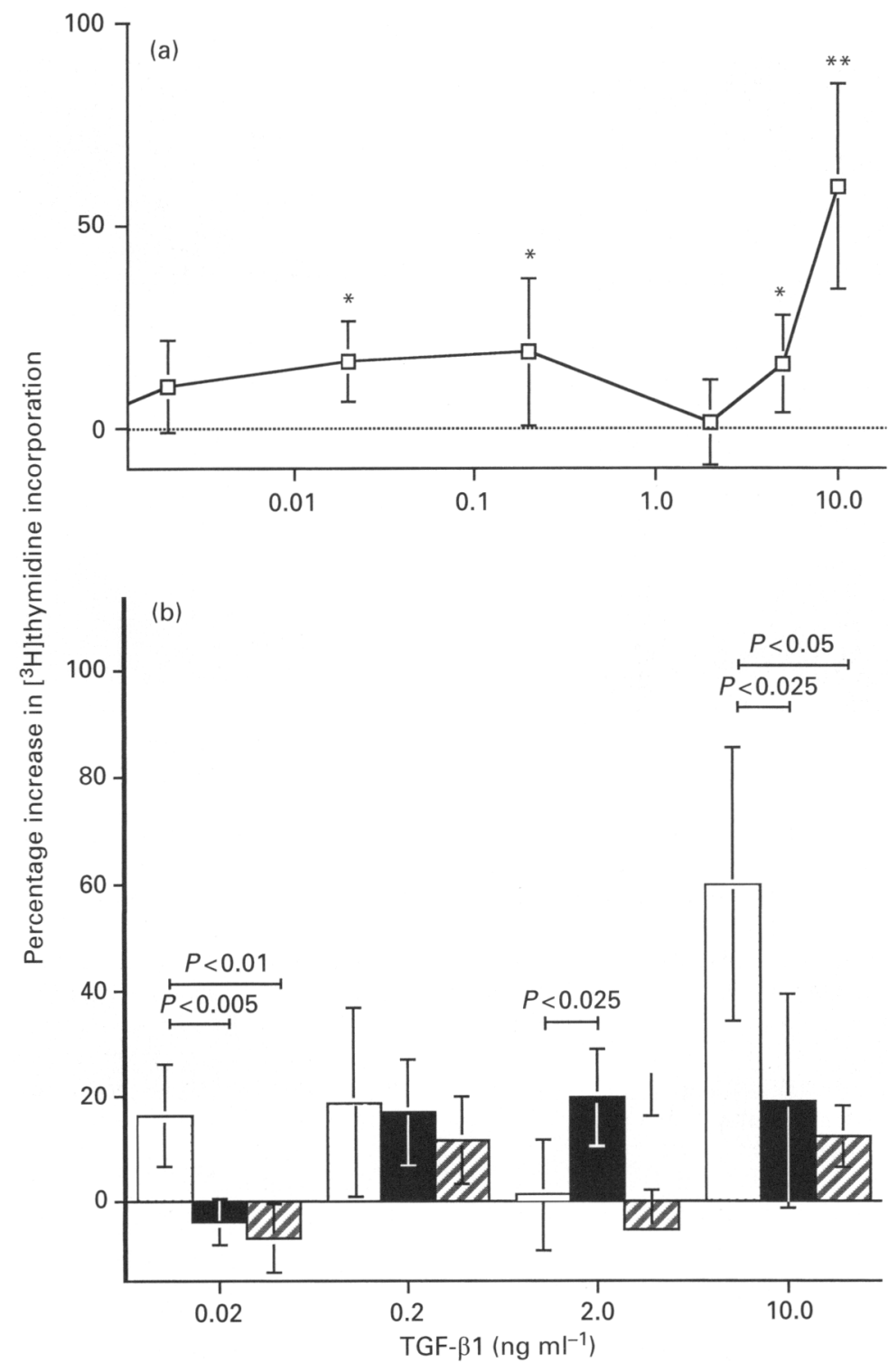

Fig. 4. $\left[{ }^{3} \mathrm{H}\right]$ thymidine incorporation into the DNA of endoglin-positive mouse uterine stromal cells after treatment with transforming growth factor $\beta 1$ (TGF$\beta 1$ ) in the presence or absence of antibodies specific to mouse endoglin or TGF$\beta$. (a) A biphasic curve of cell proliferation was observed in response to TGF- $\beta 1$. Thymidine incorporation was significantly increased by approximately $20 \%$ after incubation with TGF- $\beta 1$ at concentrations of $0.02(P<0.025)$ and $0.2 \mathrm{ng}$ $\mathrm{ml}^{-1} \quad(P<0.05)$. No stimulation was observed at $2.0 \mathrm{ng} \mathrm{ml}^{-1}$. Thymidine incorporation was stimulated by approximately $20 \%$ at a concentration of $5 \mathrm{ng}$ TGF- $\beta 1 \mathrm{ml}^{-1}(P<0.025)$ and by approximately $60 \%$ at $10 \mathrm{ng}$ TGF- $\beta 1 \mathrm{ml}^{-1}(P<$ 0.005 ). (b) Increases in DNA synthesis induced by TGF- $\beta 1$ at concentrations of 0.02 and $10.0 \mathrm{ng} \mathrm{ml}^{-1}$ were significantly inhibited by $\mathrm{mAb} \mathrm{MJ7/18}(P<0.005$ and 0.025$)$ and TGF- $\beta$ neutralizing antibodies $(P<0.01$ and 0.05$)$. At $2 \mathrm{ng} \mathrm{ml}^{-1}$, TGF- $\beta 1$ had no effect, while the addition of anti-endoglin significantly increased the rate of thymidine incorporation $(P<0.025)$. Values represent means \pm SEM; ${ }^{*} P \leq 0.05,{ }^{* *} P \leq 0.01$. $\square$, TGF- $\beta 1 ; \square$, TGF- $\beta 1+\mathrm{mAb}$ MI7/18; $\boldsymbol{Q}$, TGF- $\beta 1+$ anti-TGF- $\beta$.

using ${ }^{125}$ I-labelled TGF- $\beta 1$ revealed the presence of T $\beta R I$, $T \beta R I I$ and betaglycan. Immunoprecipitation of total cell lysates with polyclonal anti-endoglin serum indicated that endoglin expressed by uterine stromal cells binds TGF- $\beta 1$ and interacts with T $\beta R I$ and T $\beta$ RII. Endoglin- ${ }^{-125}$ I-labelled
TGF- $\beta 1$ complexes migrated to endoglin monomer and dimer immunoprecipitated from TGF- $\beta 1$ affinity labelled mouse fibroblast NCTC-2071 cells analysed under reducing and non-reducing conditions, respectively (St-Jacques et al., 1994). Monomeric endoglin migrated slightly above T $\beta R I I$ and 
(a)

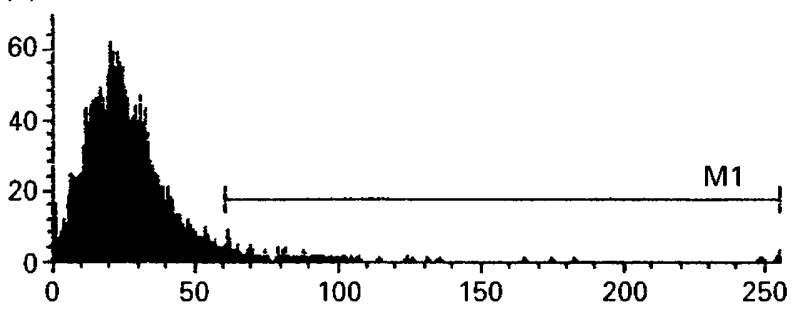

(c)

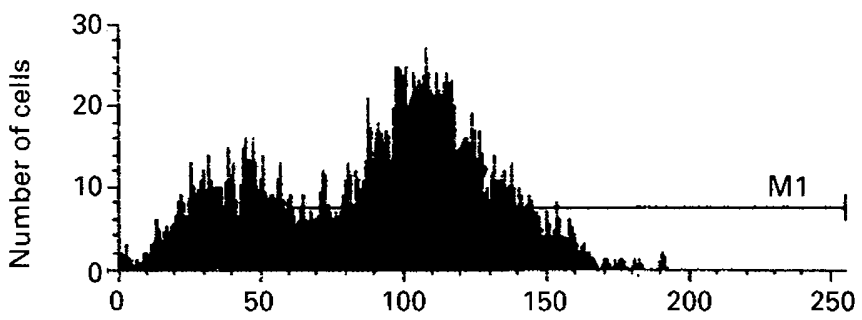

(e)

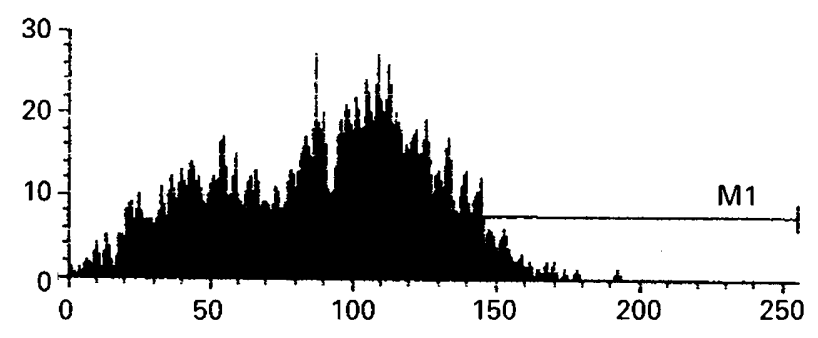

(b)

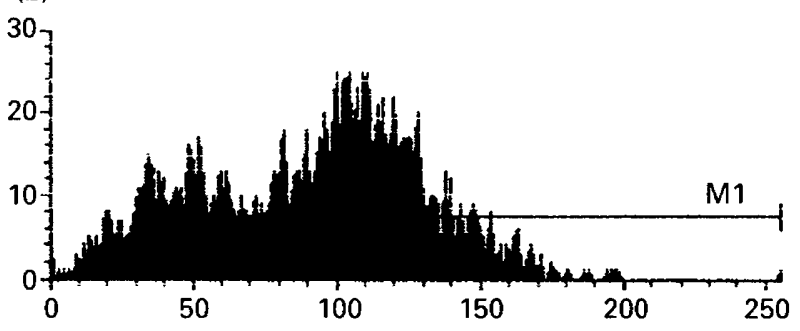

(d)

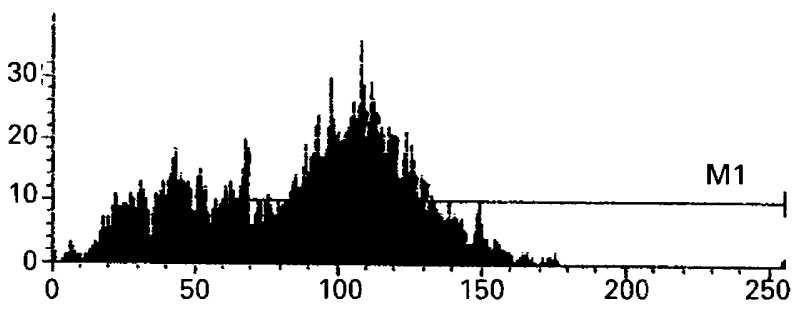

Relative fluorescence intensity (arbitrary units)

Fig. 5. Flow cytometric analysis of endoglin expression at the surface of mouse uterine stromal cells after treatment with different concentrations of transforming growth factor $\beta 1$ (TGF- $\beta 1$ ). Freshly isolated stromal cells were incubated with increasing concentrations of TGF- $\beta 1$ for $48 \mathrm{~h}$ and the expression of endoglin was evaluated by flow cytometry using $\mathrm{mAb} M \mathrm{MJ} / 18$. Although no staining is observed with control non-immune rat IgG (a), approximately $60 \%$ of uterine stromal cells expressed endoglin on their surface (b). Treatment of uterine stromal cells with (c) 0.0 , (d) 1.0, (e) 2.0 and (f) $5.0 \mathrm{ng} \mathrm{TGF-} \beta 1 \mathrm{ml}^{-1}$ did not affect the expression of endoglin. M1 represents the area of relative fluorescence intensity corresponding to cells expressing endoglin, as determined by comparing the pattern of non-specific fluorescence after incubation of cells with negative control (rat IgG) with that after incubation with anti-endoglin (MJ7/18).

was visualized best by comparing the specific non-reduced and reduced immunoprecipitates. Furthermore, coimmunoprecipitation of faint bands corresponding to T $\beta R I$ and T $\beta$ RII indicated that endoglin and the TGF- $\beta$ signalling receptors interact with each other on the surface of uterine stromal cells in the presence of ligand, as reported for pig endothelial cells (Yamashita et al., 1994), human bone marrow stromal cells (Robledo et al., 1996) and pre-B leukaemic cells (Zhang et al., 1996). These results indicate that endoglin on uterine stromal cells may function as a modulator of the effects of TGF- $\beta$, as demonstrated in U-937 monocytic cells (Lastres et al., 1996) and invading cytotrophoblast (Caniggia et al., 1997).

T $\beta R I, T \beta R I I$ and betaglycan are synthesized and expressed by uterine stromal and epithelial cells in cyclic uterus and decidua of different species (Chegini et al., 1994; Roelen et al., 1994; Tang et al., 1994; Das et al., 1997; Ando et al., 1998). Five
TGF- $\beta$ binding proteins have been identified on human endometrial stromal cells (Dumont et al., 1995). However, although the presence of T $\beta R I, T \beta R I I$, and betaglycan as well as two glycosyl-phosphatidylinositol (GPI)-anchored proteins were reported by Dumont et al . (1995), endoglin-125Ilabelled TGF- $\beta$ complexes were not detected. Since endoglin is expressed in the stroma of human endometrium (S. StJacques, P. DesRosiers, C. Nielly, M. Lamothe and D. Provencher, unpublished), the absence of TGF- $\beta$-labelled endoglin complexes might be explained by the fact that endoglin could not be readily detected in total cell lysates without immunoprecipitation (Cheifetz et al., 1992). After chemical crosslinking, endoglin-TGF- $\beta 1$ complexes comigrated with T $\beta R$ RI under reducing conditions and with the $180 \mathrm{kDa}$ GPI-anchored protein under non-reducing conditions (Cheifetz et al., 1992; Dumont et al., 1995; Robledo et al., 1996). Since endoglin, T $\beta R I$ and T $\beta$ RII were co- 
precipitated by antibodies to either endoglin or T $\beta$ RII in the presence of ligand in other types of cell (Yamashita et al., 1994; Robledo et al., 1996; Zhang et al., 1996), detection of endoglin-TGF- $\beta 1$ complexes would be expected after immunoprecipitation of affinity labelled human endometrial cell lysates with anti-T $\beta$ RII. However, immunoprecipitated complexes were analysed after electrophoresis under reducing conditions (Dumont et al., 1995) which do not allow T $\beta$ RII-TGF- $\beta 1$ and endoglin-TGF- $\beta 1$ complexes to be distinguished. Further studies are required to verify that endoglin expressed on human endometrial cells binds to TGF- $\beta 1$ and interacts with signalling receptors.

Overall, the results of the present study demonstrate that treatment of endoglin-positive mouse uterine stromal cells with TGF- $\beta 1$ significantly stimulates DNA synthesis, as reported for human endometrial stromal cells (Hammond et al., 1993; Marshburn et al., 1994; Tang et al., 1994; Dumont et al., 1995). Furthermore, a biphasic curve of proliferation in response to the growth factor was observed: there was a slight increase in thymidine incorporation at the lower concentrations investigated, followed by an absence of response at $2 \mathrm{ng} \mathrm{ml}^{-1}$, and a stimulation at higher concentrations of TGF- $\beta 1$. Similarly, Tang et al. (1994) observed that TGF- $\beta 1$ did not have an effect on the proliferation of human endometrial cells at $1 \mathrm{ng} \mathrm{ml}^{-1}$, whereas lower concentrations $\left(\leq 0.5 \mathrm{ng} \mathrm{ml}^{-1}\right)$ exerted a stimulatory effect. However, the increase in thymidine incorporation into mouse uterine stromal cells in response to concentrations of TGF- $\beta 1<0.5 \mathrm{ng} \mathrm{ml}^{-1}$ was smaller than that reported for human cells (Hammond et al., 1993; Tang et al., 1994). This difference might be explained by species variation and the phase of the cycle at which uterine tissues were isolated. A bimodal proliferative response to TGF- $\beta 1$ was observed in human smooth muscle cells, chondrocytes and fibroblasts (Battegay et al., 1990).

Significant inhibition of $\left[{ }^{3} \mathrm{H}\right]$ thymidine incorporation was observed in the presence of $\mathrm{mAb} \mathrm{MJ} / 18$ after treatment of stromal cells with 0.02 and $10.0 \mathrm{ng}$ TGF- $\beta 1 \mathrm{ml}^{-1}$. Interestingly, at $2 \mathrm{ng}$ TGF- $\beta 1 \mathrm{ml}^{-1}$, anti-mouse endoglin significantly stimulated stromal cell proliferation, whereas the growth factor alone had no effect. Since endoglin modulates cellular responses to TGF- $\beta 1$ (Lastres et al., 1996; Caniggia et al., 1997), the obstruction of endoglin molecules by specific antibodies might alter the stromal cell proliferative response to the growth factor. Thus, the present study indicates that endoglin is involved in the regulation of uterine stromal cell proliferation in response to TGF- $\beta 1$.

The expression of endoglin is upregulated by TGF- $\beta 1$ on activated monocytes (Lastres et al., 1996) and bone marrow stromal cells (Robledo et al., 1998). Since TGF- $\beta 1$ is synthesized and secreted by uterine stromal and epithelial cells in the mouse uterus (Tamada et al., 1990; Manova et al., 1992; Roelen et al., 1994; Das et al., 1997), the effect of this growth factor on the expression of endoglin on mouse uterine stromal cells was investigated. The results demonstrate that treatment of freshly isolated cells with TGF- $\beta 1$ has no effect on the expression of endoglin at the surface of uterine stromal cells.

In preparation for implantation, a wave of fibroblast-like cell proliferation is observed in the uterine stroma to increase the fibroblast population capable of undergoing decidualization (Moulton and Koenig, 1984; Abrahamsohn and Zorn, 1993). It has been proposed that TGF- $\beta 1$ may act to stimulate stromal cell proliferation in preparation for decidualization (Marshburn et al., 1994). On the basis of the critical functions attributed to TGF- $\beta$ in the uterus (Godkin and Doré, 1998), the high expression of endoglin in the endometrial stroma (St-Jacques et al., 1994), and the demonstration that endoglin is involved in the mediation of cellular effects of this growth factor on uterine stromal cells, it is likely that endoglin is an important regulator of the actions of TGF- $\beta$ in the uterine stroma.

The authors wish to thank Michelle Letarte from the Hospital for Sick Children of Toronto, Canada, for providing the rabbit polyclonal antibody 1256:4b raised against human endoglin, and Eugene Butcher of Standford University School of Medicine, Standford, CA, USA, for providing the rat monoclonal anti-mouse endoglin MJ7/18. They also thank Marie-Josée Bergeron for helpful discussion and review of the manuscript. This work was supported by grant MT-12703 from the Medical Research Council of Canada. S. St-Jacques is a Junior Scholar from Fonds de la Recherche en Santé du Québec (960141-103).

\section{References}

Abrahamsohn PA and Zorn TMT (1993) Implantation and decidualization in rodents Journal of Experimental Zoology 266 603-628

Ando N, Hirahara F, Fukushima J, Kawamoto S, Okuda K, Funabashi T, Gorai $I$ and Minaguchi $\mathbf{H}$ (1998) Differential gene expresssion of TGF- $\beta$ isoforms and TGF- $\beta$ receptors during the first trimester of pregnancy at the human maternal-fetal interface American journal of Reproductive Immunology 40 48-56

Battegay EJ, Raines EW, Seifert RA, Bowen-Pope DF and Ross R (1990) TGF$\beta$ induces bimodal proliferation of connective tissue cells via complex control of an autocrine PDGF loop Cell 63 515-524

Bigsby RM, Cooke PS and Cunha GR (1986) A simple efficient method for separating murine uetrine epithelial and mesenchymal cells American Journal of Physiology 251 E630-E636

Bischof P, Redar M, Gindre P, Vassilakos P and Campana A (1993) Localization of alpha 2, alpha 5 and alpha 6 integrin subunits in human endometrium, decidua and trophoblast European Journal of Obstetrics and Gynaecology and Reproductive Biology 51 217-226

Bruner KL, Rodgers WH, Gold LI, Korc M, Hargrove JT, Matrisian LM and Osteen KG (1995) Transforming growth factor beta mediates the progesterone suppression of an epithelial metalloproteinase by adjacent stroma in the human endometrium Proceedings National Academy of Sciences USA $927362-7366$

Caniggia I, Taylor CV, Knox JW, Lye SJ and Letarte M (1997) Endoglin regulates trophoblast differentiation along the invasive pathway in human placental villous explants Endocrinology $1384977-4988$

Casslén B, Sandberg T, Gustavsson B, Willén R and Nilbert M (1998) Transforming growth factor $\beta 1$ in the human endometrium. Cyclic variation, increased expression by estradiol and progesterone, and regulation of plasminogen activators and plasminogen activator inhibitor-1 Biology of Reproduction 58 1343-1350

Chegini N, Rossi MJ and Masterson BJ (1992) Platelet-derived growth factor (PDGF), epidermal growth factor (EGF), and EGF and PDGF $\beta$-receptors in human endometrial tissue: localization and in vitro action Endocrinology 130 2373-2385

Chegini N, Zhao Y, Williams RS and Flanders KC (1994) Human uterine tissue throughout the menstrual cycle expresses transforming growth factor- $\beta 1$ (TGF- $\beta 1$ ), TGF- $\beta 2$, TGF- $\beta 3$, and type II receptor messenger ribonucleic acid and protein and contains $\left[{ }^{125} \mathrm{I}\right]$ TGF- $\beta 1$ binding sites Endocrinology $135439-449$

Cheifetz S, Like B and Massagué J (1986) Cellular distribution of type I and type II receptors for transforming growth factor- $\beta$ loumal of Biological Chemistry $2619972-9978$

Cheifetz S, Andres JL and Massagué J (1988) The transforming growth factorDownloaded from Bioscientifica.com at 04/26/2023 12:56:55PM 
$\beta$ receptor type III is a membrane proteoglycan. Domain structure of the receptor Journal of Biological Chemistry 263 16984-16991

Cheifetz S, Bellon T, Cales C, Vera S, Bernabeu C, Massagué J and Letarte M (1992) Endoglin is a component of the transforming growth factor- $\beta$ receptor in human endothelial cells Journal of Biological Chemistry 267 $19027-19030$

Chen R-H, Moses HL, Maruoka EM, Derynck R and Kawabata M (1995) Phosphorylation-dependent interaction of the cytoplasmic domains of the type I and type II transforming growth factor- $\beta$ receptors journal of Biological Chemistry 27012 235-12 241

Clark DA, Flanders KC, Banwatt D, Millar-Book W, Manuel J, StedronskaClark J and Rowley B (1990) Murine pregnancy decidua produces a unique immunosuppressive molecule related to transforming growth factor- $\beta 2$ Journal of Immunology 144 3008-3014

Das SK, Lim H, Wang J, Paria BC, BazDresch M and Dey SK (1997) Inappropriate expression of human transforming growth factor (TGF)- $\alpha$ in the uterus of transgenic mouse causes downregulation of TGF- $\beta$ receptors and delays the blastocyst attachment reaction Journal of Molecular Endocrinology 18 243-257

Dumont N, O'Connor-McCourt MD and Philip A (1995) Transforming growth factor $\beta$ receptors on human endometrial cells: identification of the type I, II and III receptors and glycosyl-phosphatidylinositol anchored TGF$\beta$ binding proteins Molecular and Cellular Endocrinology 111 57-66

Flanders KC, Marascalco BA, Roberts AB and Sporn MA (1991) Transforming growth factor $\beta$ : a multifunctional regulatory peptide with actions in the reproductive system. In Growth Factors in Reproduction pp 23-37. Springer-Verlag, New York

Ge AZ and Butcher EC (1994) Cloning and expression of a cDNA encoding mouse endoglin, an endothelial cell TGF- $\beta$ ligand Gene 138 201-206

Godkin JD and Doré JJE (1998) Transforming growth factor $\beta$ and the endometrium Reviews of Reproduction 31-6

Gougos A and Letarte $\mathbf{M}$ (1988) Identification of a human endothelial cell antigen with monoclonal antibody $44 \mathrm{G} 4$ produced against a pre-B leukemic cell line Journal of Immunology 141 1925-1933

Gougos A and Letarte M (1990) Primary structure of endoglin, an RGDcontaining glycoprotein of human endothelial cells Journal of Biological Chemistry 265 8361-8364

Graham CH and Lala PK (1992) Mechanisms of placental invasion of the uterus and their control Biochemistry and Cell Biology 70 867-874

Grosskinsky CM, Yowell CW, Sun J, Parise LV and Lessey BA (1996) Modulation of integrin expression in endometrial stromal cells in vitro. journal of Clinical Endocrinology and Metabolism 81 2047-2054

Hammond MG, Oh S-T, Anners J, Surrey ES and Halme J (1993) The effect of growth factors on the proliferation of human endometrial stromal cells in culture American Journal of Obstetrics and Gynecology 168 1131-1138

Heldin CH, Miyazono K and ten-Dijke P (1997) TGF-beta signalling from cell membrane to nucleus through SMAD proteins Nature 390 465-471

Iwahashi M, Muragaki Y, Ooshima A, Yamoto M and Nakano R (1996) Alterations in distribution and composition of the extracellular matrix during decidualization of the human endometrium Journal of Reproduction and Fertility 108 147-155

Jacobs AL and Carson DD (1991) Proteoglycan synthesis and metabolism by mouse uterine stroma cultured in vitro. Journal of Biological Chemistry 26615 464-15 473

Lastres P, Letamendia A, Zhang H et al. (1996) Endoglin modulates cellular responses to TGF- $\beta 1$ Journal of Cell Biology 133 1109-1121

Lessey BA, Castelbaum AJ, Buck CA, Lei Y, Yowell CW and Sun J (1994) Further characterization of endometrial integrins during the menstrual cycle and in pregnancy Fertility and Sterility 62 497-506

Letarte M, Greaves A and Vera S (1994) CD105 (endoglin) cluster report. In Leukocyte Typing V: White Cell Differentiation Antigen pp 1756-1759. Oxford University Press, Oxford

Lopez-Casillas F, Cheifetz S, Doody J, Andres JL, Lane WS and Massagué J (1991) Structure and expression of the membrane proteoglycan betaglycan, a component of the TGF- $\beta$ receptor system Cell 67 785-795

Lopez-Casillas F, Wrana JL and Massagué J (1993) Betaglycan presents ligand to the TGF- $\beta$ signaling receptor Cell 73 1435-1444

McAllister KA, Grogg KM, Johnson DW et al. (1994) Endoglin, a TGF- $\beta$ binding protein of endothelial cells, is the gene for hereditary haemorrhagic telangiectasia type 1 Nature Genetics 8345-351

Mani SK, Julian J, Lampelo S and Glasser SR (1992) Initiation and maintenance of in vitro decidualization are independent of hormonal sensitization in vivo. Biology of Reproduction 47 785-799
Manova K, Paynton BV and Bachvarova RF (1992) Expression of activins and TGF- $\beta 1$ and $-\beta 2$ RNAs in early postimplantation mouse embryos and uterine decidua Mechanisms of Development 36 141-152

Marshburn PB, Arici AM and Casey ML (1994) Expression of transforming growth factor- $\beta 1$ messenger ribonucleic acid and the modulation of deoxyribonucleic acid synthesis by transforming growth factor- $\beta 1$ in human endometrial cells American Journal of Obstetrics and Gynecology 170 1152-1158

Massagué J (1996) TGF- $\beta$ signaling: receptors, transducers and MAD proteins Cell 85 947-950

Massagué J and Like B (1985) Cellular receptors for type $\beta$ transforming growth factor. Ligand binding and affinity labelling in human and rodent cell lines Journal of Biological Chemistry $2602636-2645$

Mitchell EJ, Fitz-Gibbon L and O'Connor-McCourt M (1992) Subtypes of betaglycan and of type I and type II transforming growth factor- $\beta$ (TGF- $\beta$ ) receptors with different affinities for TGF- $\beta 1$ and TGF- $\beta 2$ are exhibited by human placental trophoblast cells Journal of Cellular Physiology 150 334-343

Miyazono K (1997) TGF- $\beta$ receptors and signal transduction International Journal of Hematology 65 97-104

Moulton BC and Koenig BB (1984) Uterine deoxyribonucleic acid synthesis during preimplantation in precursors of stromal cell differentiation during decidualization Endocrinology 115 1302-1307

Mulholland J, Aplin JD, Ayad S, Hong L and Glasser SR (1992) Loss of collagen type VI from rat endometrial stroma during decidualization Biology of Reproduction 46 1136-1143

O'Connell PJ, McKenzie A, Fisicaro N, Rockman SP, Pearse MJ and D'Apice AJF (1992) Endoglin: a 180-kD endothelial cell and macrophage restricted differentiation molecule Clinical and Experimental Immunology 90 154-159

Robledo MM, Hidalgo A, Lastres P, Arroyo AG, Bernabéu C, SanchezMadrid F and Teixido J (1996) Characterization of TGF-beta 1-binding proteins in human bone marrow stromal cells British Journal of Haematology $93507-514$

Robledo MM, Ursa MA, Sanchez-Madrid F and Teixido J (1998) Associations between TGF-beta1 receptors in human bone marrow stromal cells British Journal of Haematology 102 804-811

Rodgers WH, Matrisian LM, Giudice LC, Dsupin B, Cannon P, Svitek C, Gorstein F and Osteen KG (1994) Patterns of matrix metalloproteinase expression in cycling endometrium imply differential functions and regulation by steroid hormones Journal of Clinical Investigations 94 946-953

Roelen BA, Lin HY, Knezevic V, Freund E and Mummery CL (1994) Expression of TGF-betas and their receptors during implantation and organogenesis of the mouse embryo Developmental Biology 166 716-728

Rotello RJ, Lieberman RC, Furchio AF and Gerschenson LE (1991) Coordinated regulation of apoptosis and cell proliferation by transforming growth factor $\beta 1$ in cultured uterine epithelial cells Proceedings National Academy of Sciences USA 88 3412-3415

Sandberg T, Eriksson P, Gustavsson B and Casslén B (1997) Differential regulation of the plasminogen activator inhibitor-1 (PAI-1) gene expression by growth factors and progesterone in human endometrial stromal cells Molecular Human Reproduction 3 781-787

Shull MM and Doetschman T (1994) Transforming growth factor- $\beta 1$ in reproduction and development Molecular Reproduction and Development 39 239-246

St-Jacques S, Cymerman U, Pece N and Letarte M (1994) Molecular characterization and in situ localization of murine endoglin reveal that it is a transforming growth factor $-\beta$ binding protein of endothelial and stromal cells Endocrinology 134 2645-2657

Tabibzadeh S (1992) Patterns of expression of integrin molecules in human endometrium throughout the menstrual cycle Human Reproduction 7 876-882

Takahashi T, Eitzman B, Bossert NL, Walmer D, Sparrow K, Flanders KC, McLachlan J and Gray Nelson K (1994) Transforming growth factors $\beta 1$, $\beta 2$ and $\beta 3$ messenger RNA and protein expression in mouse uterus and vagina during estrogen-induced growth: a comparison to other estrogen-regulated genes Cell Growth and Differentiation 5 919-935

Tamada H, McMaster MT, Flanders KC, Andrews GK and Dey SK (1990) Cell type-specific expression of transforming growth factor- $\beta 1$ in the mouse uterus during the periimplantation period Molecular Endocrinology 4 965-972

Tang X-M, Zhao Y, Rossi MJ, Abu-Rustum RS, Ksander GA and Chegini N (1994) Expression of transforming growth factor- $\beta$ (TGF- $\beta$ ) isoforms and TGF- $\beta$ type II receptor messenger ribonucleic acid and protein, and the effect of TGF- $\beta$ s on endometrial stromal cell growth and protein degradation in vitro. Endocrinology 135 450-459

Ueda $M$, Ueki $M$, Tsurunaga T, Yamada T, Okamoto $Y$, Seiki $Y$, Iwai E and Sugimoto $\mathbf{O}$ (1992) In vitro study on the effect of sex steroid and growth 
factor on growth and laminin, collagen IV, and tissue plasminogen activator production of normal endometrial cells and endometrial cancer cells in culture Acta Obstetrica Gynaecologica Japonica 44 1219-1226

Ventura F, Doody J, Liu F, Wrana JL and Massagué J (1994) Reconstitution and transphosphorylation of TGF- $\beta$ receptor complexes EMBO journal 13 5581-5589

Wrana JL, Attisano L, Carcamo J, Zentella A, Doody J, Laiho M, Wang X-F and Massagué $J$ (1992) TGF $\beta$ signal through a heteromeric protein kinase receptor complex Cell 71 1003-1014

Wrana JL, Attisano L, Wieser R, Ventura F and Massagué J (1994) Mechanism of activation of the TGF- $\beta$ receptor Nature 370 341-347
Yamashita H, Ichijo H, Grimsby S, Morén A, ten Dijke P and Miyazono K (1994) Endoglin forms a heteromeric complex with the signaling receptors for transforming growth factor- $\beta$ journal of Biological Chemistry 269 1995-2001

Zhang H, Shaw ARE, Mak A and Letarte M (1996) Endoglin is a component of the transforming growth factor (TGF)- $\beta$ receptor complex of human pre$B$ leukemic cells Journal of Immunology 156 565-573

Zhang L, Rees MC and Bicknell R (1995) The isolation and long-term culture of normal human endomerial epithelium and stroma. Expression of mRNAs for angiogenic polypeptides basally and on estrogen and progesterone challenges Journal of Cell Sciences 108 323-331 